\title{
ABO and Rh (D) Blood Groups among the Desuri Reddis of Chittoor District, Andhra Pradesh
}

\author{
K. S. N. Reddy and G. Sudha \\ Department of Anthropology, Sri Venkateswara University, Tirupati 517 502, \\ Andhra Pradesh, India
}

KEYWORDS Blood Groups. Desuri Reddis. Variation.

\begin{abstract}
A total of 190 unrelated Desuri Reddi individuals from Chittoor district, Andhra Pradesh were studied for the phenotype and allele frequency distribution of $\mathrm{ABO}$ and $\mathrm{Rh}(\mathrm{D})$ blood groups. The order of occurrence of $\mathrm{ABO}$ phenotypes is $\mathrm{O}>\mathrm{B}>\mathrm{A}$. The corresponding allele frequencies are found to be $0.6728(O) ; 0.1839(B)$ and $0.1433(A)$. The allele frequency of $D(0.7098)$ is more than $d(0.2902)$. The present study was compared with the other studies reported to understand the affinity between them.
\end{abstract}

\section{INTRODUCTION}

$\mathrm{ABO}$ and Rhesus (Rh) blood group antigens are hereditary characters and are useful in population genetic studies, researching population migration patterns, as well as resolving certain medicolegal issues, particularly of disputed paternity and more importantly in compatibility test in blood transfusion practice. The knowledge of the distribution of $\mathrm{ABO}$ and $\mathrm{Rh}$ blood groups at local and regional levels are helpful in the effective management of blood banks and in blood transfusion services. Further, blood group systems are useful to determine the genetic variation within and between the populations. During the last four decades, numerous studies have been carried out on the genetic composition of various endogamous population groups in India (Bhasin et al. 1994, 2001). However, genetic studies among Reddy caste in Andhra Pradesh are very limited. Hence, in the present study the distribution of $\mathrm{ABO}$ and Rhesus blood groups has been reported among the Desuri Reddis, a sub-caste of the major caste Reddi of Chittoor district, Andhra Pradesh.

\section{MATERIALS AND METHODS}

The blood samples were drawn from randomly selected 190 unrelated individuals of both the sexes of Desuri Reddis, a sub-caste of a major

Address for correspondence:

Dr. K.S.N. Reddy, Assistant Professor

Department of Anthropology, Sri Venkateswara

University, Tirupati 517 502, Andhra Pradesh, India

E-mail: katarisnr@yahoo.co.in caste the Reddi of Chittoor district in Southern Andhra Pradesh. The Reddis are one of the most predominant and largest Telugu speaking castes in Andhra Pradesh among whom more than 88 sub-castes were reported. (Surendranatha Reddy, 1993). Desuri Reddis, selected for the present study is found to be distributed mainly in the Chittoor district of Southern Andhra Pradesh. Agriculture is their mainstay of economy. Subcaste endogamy is strictly maintained. Monogamy is the general pattern of marriage. Literacy rate is high compared to the neighbouring caste populations. Nuclear families are more common. The blood samples were collected according to the methods of Race and Sanger (1962). All samples were tested for the ABO and Rh blood group systems using anti-A, anti-B and anti-D sera. Gene frequencies were computed according to Mourant et al. (1976).

\section{RESULTS AND DISCUSSION}

$\mathrm{ABO}$ and $\mathrm{Rh}$ genes and phenotypes vary widely across races and geographical boundaries despite the fact that the antigens involved are stable throughout life. The resultant polymorphism remains important in population genetic studies, estimating the availability of compatible blood. The present study is, therefore, useful in providing information on the status of $\mathrm{ABO}$ and Rh blood group distribution in the Desuri Reddis.

The distribution of $\mathrm{ABO}$ blood groups is concerned (Table1), the group ' $\mathrm{O}$ ' (47.37\%) is the most frequently encountered phenotype in the population under the study. This observation is in accordance with the previous reports from other 
Table 1: Percentage distribution of $\mathrm{ABO}$ phenotypes and allele frequencies

\begin{tabular}{lcccc}
\hline Phenotypes & Observed Number & $\%$ & Expected number & Allele frequency \\
\hline O & 90 & 47.37 & 85.99 & $O=0.6728$ \\
B & 49 & 25.79 & 53.45 & $B=0.1839$ \\
A & 36 & 18.95 & 40.54 & $A=0.1433$ \\
AB & 15 & 7.89 & 10.02 & 1.0000 \\
\hline Total & 190 & 100.00 & 190.00 & \\
\hline
\end{tabular}

$\chi^{2}=3.5401$

Table 2: Percentage distribution of $R h$ (D) phenotypes and allele frequencies

\begin{tabular}{lrrr}
\hline Phenotypes & No. & \multicolumn{1}{c}{$\%$} & Allele frequency \\
\hline $\mathrm{Rh}+\mathrm{ve}$ & 174 & 90.58 & $D=0.7098$ \\
$\mathrm{Rh}-\mathrm{ve}$ & 16 & 8.42 & $d=0.2902$ \\
\hline Total & 190 & 100.00 & 1.0000 \\
\hline
\end{tabular}

parts of Andhra Pradesh. With regard to the other phenotypes of $\mathrm{ABO}$ blood groups, the frequency of group ' $\mathrm{B}$ ' is $25.79 \%$, and group ' $\mathrm{A}$ ' is $18.95 \%$, while 'AB' group was the least encountered phenotype with a frequency of $7.89 \%$ among the samples studied. The order of ABO percentage frequencies are $\mathrm{O}>\mathrm{B}>\mathrm{A}>\mathrm{AB}$. With regard to the allele frequency in the Desuri Reddis, allele $O$ is observed with the highest frequency $(0.6728)$ than $B(0.1839)$ and $A(0.1433)$. The insignificant $\chi^{2}$ value (3.5401) shows that the study population is under genetic equilibrium. Table 2 shows the frequency of $\mathrm{Rh}(\mathrm{D})$ phenotypes among the study population. In the present study the frequency of Rh-D positive phenotype is $91.58 \%$ and $8.42 \%$ were $\mathrm{Rh}$ negative and the allele frequencies are being 0.7098 for $D$ and 0.2902 for $d$ alleles.

\section{REFERENCES}

Bhasin MK, Walter H, Danker-Hopfe H 1994. People of India: An Investigation of Biological Variability in Ecological, Ehno-economic and Linguistic groups. Delhi: Kamla-Raj Enterprises.

Bhasin MK, Walter H 2001. Genetics of Castes and Tribes of India. Delhi: Kamla-Raj Enterprises.

Mourant AE, Kopec AC, Domanieswska-Sobezek K 1976. The Distribution of the Human Blood Groups and other Polymorphisms. Oxford: Black well Scientific publication.

Race RR, Sanger R 1962. Blood Groups in Man. $4^{\text {th }}$ Editon, Oxford: Blackwells.

Surendranadha Reddy K 1993. Genetic variation among the Reddis of Andhra Pradesh. Ph.D., thesis, S.V. University, Tirupati. 